\title{
HUMANISASI DALAM PARADIGMA PENDIDIKAN YANG NYARIS TERABAIKAN
}

\author{
Evi Masyithah, M. Ag \\ Dosen pada Program Studi Pendidikan Agama Islam Fakultas Ilmu Keislaman \\ (FIK) sekaligus Dekan Fakultas Psikologi dan Ilmu Pendidikan (FPIP) Universitas \\ Islam Raden Rahmat Malang \\ evi.masyithah@uniramalang.ac.id
}

\begin{abstract}
Abstrak
Eksistensi suatu negara pada dasarnya ditentukan oleh dinamika semberdaya manusia (human resourches) yang berkualitas, terus bergerak, membangun diri dan masyarakat. Tujuan pembangunan secara makro adalah terbentuknya manusia seutuhnya. Arah tujuan pembangunan ini pada hakekatnya mengembalikan manusia pada kodratnya. Pendidikan, sebagai salah satu subsistem dari pembangunan, dianggap paling korelat untuk mewujudkan cita-cita di atas. Jika pendidikan diharapkan dapat mewujudkan konsep pembentukan manusia seutuhnya, maka jawaban yang dianggap relevan adalah penyelenggaraan pendidikan yang menggunakan landasan "pendekatan humanistik". Pendidikan yang berlandaskan konsep humanistik pada hakekatnya bertujuan untuk menciptakan kondisi belajar mengajar yang memberikan peluang bagi anak didik untuk mengaktualisasikan kemampuan yang ada pada dirinya. Dengan pendekatan humanistik, orang tidak perlu khawatir bahwa anak didik hanya menjadi orang-orang alim tapi bodoh. Tujuan pokok dari pendidikan yang humanistik adalah agar anak didik mendapatkan perlakuan yang manusiawi dengan meng-hargai martabatnya sebagai pribadipribadi yang memiliki potensi untuk tumbuh dan berkembang.
\end{abstract}

\section{Pendahuluan}

Sistem pendidikan atau yang lebih khusus menyangkut pola-pola kebijakan pendidikan yang diterapkan di negara-negara berkembang, termasuk Indonesia, hampir memiliki tipologi yang sama, yakni fleksibilitas. Di Indonesia, untuk membuktikan terjadinya fleksibilitas dalam orientasi pendidikannya dilukiskan dalam statement sinis : "ganti menteri ganti kebijakan." Tersirat di dalamnya adalah intensitas perubahan pola-pola kebijakan pendidikan yang masih dilakukan mengikuti periodisasi jabatan menteri. Kadang-kadang orientasi perubahan yang dilakukan hanya bersifat sensasional yang sangat atributif dan kurang menyentuh dimensi substansial dalam pendidikan. 
Oleh karena itu, dapat dipahami kalau sampai saat ini masih terjadi ambiguitas dalam menetapkan pijakan yang tepat untuk menetapkan pola-pola kebi-jakan kependidikan. Dimensi politik yang diterapkan sebagai "pewarna" dalam setiap lini kehidupan, termasuk kebijakan pen-didikan, pada gilirannya hanya akan menambah ambiguitasan itu. Masih segar dalam ingatan kita ketika masa Pemerintahan Orde Baru Mendikbud Wardiman, mencoba menerapkan sistem pendidikan magang yang terkenal dengan sebutan "link and match", apa yang terjadi?

Era industrialisasi sebagai fe-nomena sosial telah dicoba diintrodusir menjadi falsafah dalam kebijakan pen-didikan. Lembaga pendidikan semua di-arahkan untuk mengekploitasi peserta didiknya agar menjadi lulusan yang siap pakai. Tataran logika yang paling dangkal barangkali dapat menerima. Namun, ketika sampai pada tataran yang sangat fundamental, tentang arti hakiki pen-didikan yang selalu melibatkan manusia sebagai pemegang peran tunggal, perlu adanya revisi, paling tidak secara konsep-sional.

Termasuk di dalamnya adalah konsepsi tentang tujuan pendidikan. Mardiatmaja SJ dalam Hartoko (ed) (1990 : 35) menjabarkan paling tidak ada empat tujuan pendidikan. Yaitu pengembangan pribadi, pengembangan warga negara, pengembangan kebudayaan, dan pengem-bangan bangsa. Dari keempat tujuan pendidikan itu ada tiga bidang yang harus dijadikan orientasi penggarapan sebagaimana konsep Benjamin Bloom yakni kognitif, afektif, dan psikomotorik-masing-masing bertujuan agar budi peserta didik lebih berkembang, agar sikap hatinya semakin tumbuh seimbang dan agar ke-hendak berikut tingkah lakunya menjadi kian baik dan skillnya tinggi

Jika hal demikian yang menjadi orientasinya, maka tujuan pendidikan bukanlah pertama-tama sebagai pengalihan pengetahuan, melainkan membantu agar peserta didik mampu mengembangkan potensi-potensinya untuk tahu lebih ba-nyak dan belajar terus, dalam arti yang seluas mungkin. Potensi untuk tahu lebih banyak dan belajar terus menerus dalam arti yang luas itu merupakan suatu daya dasariah manusia. Khususnya untuk menuju ke 'mengetahui diri, sesama, dan lingkungan. Bila seseorang mengetahui diri dalam konteks lengkap semacam itu, maka dia dapat 
mandiri dalam relasi dengan yang lain. Dengan demikian mereka menjadi manusia yang sebenar-benarnya.

Sehubungan dengan gagasan terakhir itu, N. Driyakarya mengartikan bahwa pendidikan adalah sebagai "pemanusiaan manusia muda". Di situ Driyarkara berpendapat bahwa pendidikan harus membantu agar seseorang secara tahu dan mau bertindak sebagai manusia dan bukan hanya secara instinktif saja. Hal ini memperkuat pemahaman bahwa pen-didikan adalah proses humanisasi; yaitu usaha agar seluruh sikap dan tindak serta aneka kegiatan seseorang benar-benar bersifat manusiawi dan semakin ma-nusiawi. Memperlihatkan pandangan-pandangan di atas, pada hakekatnya konsepsi pendidikan secara proporsional telah menempatkan manusia pada posisi yang terhormat. Hal ini sebagaimana pandangan bahwa pendidikan bersangkut paut dengan manusia. Oleh karena itu konsepsi tentang pendidikan tidak dapat tidak mengendalikan pemahaman kita mengenai apa artinya menjadi manusia. Untuk menjawab pertanyaan apa artinya menjadi manusia, dari satu sisi kita harus bertolak dari kenyataan historis, tidak semata-mata dari konsep saja. Karena dalam sejaralah manusia telah mengalami kegagalan dalam mewujudkan kemanusiaannya. Dari sisi lain, manusia sendiri juga mendefinisikan apa artinya menjadi manusia dan perumusan mengenai makna manusia juga berubah sepanjang sejarah.

\section{Dehumanisasi Dalam Pendidikan Kita}

Erich Fromm, berpendapat bahwa dalam kehidupan masyarakat di era industrialisasi ditengarai adanya fenomena yang menggejala dalam dunia pendidikan modern yang diistilahkannya dengan mode of having (model memiliki) dan mode of being (model menjadi).

Kedua model pendidikan di atas adalah bersifat antagonistis. Model yang pertama (mode of having) cenderung pada pembentukan dirinya dengan berbagai aksesori verbal dan lahiriah. Kekhasan yang tampak pada model itu adalah keinginan menguasai pelbagai objek yang dimiliki. Lazimnya untuk mewujudkan keinginan itu kadang dilakukan dengan membenarkan segala cara. Sementara itu model kedua, 
merupakan kebalikan dari model yang pertama. Salah satu ciri yang menonjol adalah adanya penghormatan akan eksistensi dan kemerdekaan sesamanya.

Melihat dua model yang digambarkan oleh Erich Fromm di atas, timbul pertanyaan, model yang manakah yang kira-kira memiliki kesamaan, paling tidak, kemiripan visi dengan pendidikan kita selama ini ? Barangkali kita setuju identik dengan yang pertama. Secara em-piris kita dapat melihat indikasi-indikasi yang timbul. Adanya orientasi materialistis yang kecenderungannya menghasilkan sikapsikap angkuh dan egoistis, dapat dijadikan pendukung atas adanya gejala yang dimaksud.

Pengalaman empiris yang lain dapat dilihat sebagai sistem pengajaran yang selama ini berkembang. Proses mengajar saat ini merupakan implementasi dari konsep "sistem penyampaian". Artinya, indikator mengajar yang baik apabila guru dapat menyampaikan bahan ajar sebaik-baiknya.

Dalam pelaksanaan pengajaran yang demikian, maka jangan diharap tumbuhnya cara belajar bermakna, tumbuhnya perkembangan kultur belajar, individu belajar, perkembangan pribadi dan jati diri1 peserta didik dapat diwujudkan. Guru diharapkan mampu menciptakan proses pembelajaran yang kondusif. Guru bukannya memamerkan kemampuan kepada siswa, melainkan guru memperhatikan kesulitan dan kekurangan siswa untuk dicarikan jalan keluar.

Kalau kita amati secara seksama bahwa sistem pembelajaran selama ini telah memberikan porsi yang dominan, atau kalau tidak diutamakan, kepada otak kecerdasan (IQ). Yang itu semua ditandai dengan prestasi akademik. Hal ini didasari oleh sebuah asumsi bahwa makin tinggi intensitas asah otak intelektual, makin tinggi pula keberhasilan pendidikan. Namun perlu disadari, ternyata dalam kehidupan tidak hanya sekedar meng-andalkan otak kecerdasan, melainkan di-barengi juga dengan otak emosional (EQ). Bahkan Dr. Daniel Goleman dalam bukunya "Emotional Intellegence" telah mematahkan mitos otak kecerdasan (IQ) itu kurang bermaslahat dalam kehidupan tanpa kehadiran otak emosional (EQ). Paradigma dasarnya bahwa manusia ber-kualitas tinggi adalah mereka yang cerdas penalaran dan cerdas emosional. 
Bahkan ada juga yang berpan-dangan bahwa sukses tidaknya seseorang menjalani proses kemanusiaan, disebabkan 80 persen oleh otak emosional dan 20 persen otak kecerdasan. Goleman melihat fenomena otak emosional ini sebagai fenomena sosial. Ini berarti bahwa masuk-nya fenomena sosial dalam ranah otak kecerdasan berporos pada lahirnya ranah otak emosional. Hal ini sebagaimana Taufiq Pasiak dalam : Revolusi IQ, EQ dan SQ : antara Neurosains dan Alqur'an (2002).

Sejalan dengan pandangan di atas, Prof. Dr. Djohar berpendapat bahwa pendidikan berwawasan kemanusiaan pada dasarnya adalah pendidikan yang menekankan pada perhatian terhadap individu manusia secara utuh, tidak hanya terbatas pada dimensi psikologiknya saja, atau hanya pada motoriknya saja, atau pada pengetahuannya saja, akan tetapi kepada keutuhan antropologik peserta didik sebagai manusia dalam arti sebagai pribadi dengan segala karakteristik fisik dan psikisnya dan dengan segala karakteristik sosial budayanya.

Fokus pendidikan berwawasan ke-manusiaan pada dasarnya mempersoalkan (1) bagaimana cara memperlakukan sa-saran pendidikan yaitu individu anak di dalam proses pendidikan yang manusiawi dan (2) bagaimana sistem pendidikan, manajemen pendidikan, penyelenggaraan pendidikan termasuk belajar mengajar dilaksanakan sehingga dapat mewujudkan perlakuan-perlakuan terhadap sasaran pendidikan itu menjadi manusiawi.

Apabila pendidikan sekarang ini baru ditekankan pada dimensi psikologiknya, maka pemikiran pen-didikan berwawasan kemanusiaan memer-lukan "shift” orientasi dari tekanan psikologiknya ke tekanan antropologik.

Tidak semua unsur pendidikan di atas dapat dikendalikan, agar pendidikan berwawasan kemanusiaan dapat diwujud-kan. Namun demikian beberapa hal dapat diperhatikan sehingga pendidikan yang menekankan dimensi keutuhan antro-pologik anak dapat dikendalikan di antara-nya adalah (1) pendidikan memberi ke-sempatan pada setiap anak untuk mengembangkan diri dan menemukan jati dirinya. (2) Pendidikan memberi kesem-patan pada setiap anak untuk membangun budaya dan individu belajar. (3) Orang tua bukan penentu pilihan pendidikan bagi anaknya. (4) Peran guru adalah "tut wuri handayani" dalam proses pendidikan dan pembelajaran. 
(5) Proses pendidikan lebih berorientasi pada diskaveri dan inkuiri dari pada sekedar menerima atau mengikuti prosedur sistematik. (6) Sekolah dan masyarakat harus menjadi lingkungan yang kondusif bagi perkembangan pribadi anak, di luar lingkungan keluarga. (7) Manajemen pendidikan dan penye-lenggaraan pendidikan harus mendukung terwujudnya proses pendidikan yang manusiawi. Namun sayang sekali kalau kita bertolak dari konteks pendidikan kita selama ini. Paling tidak telah dapat digambarkan bahwa pola-pola kebijakan pendidikan kita saat ini telah kehilangan falsafah hakikinya. Pendidikan yang pada hakekatnya merupakan proses transformasi ilmu pengetahuan dan budaya yang tujuan akhirnya adalah menempatkan manusia pada alam kemanusiaan sejati kurang dapat ditangkap secara utuh. Oleh karena itu tidak dapat dielakkan lagi terjadinya degradasi rasa kemanusiaan dalam ke-hidupan akhir-akhir ini. Atas dasar itulah maka pakar pendidikan dari Yogyakarta, Prof. Dr. Djohar, mengkritik bahwa seakan orang utan lebih berhasil mendidik Tarsan menjadi manusia yang berakal budi. Tetapi sungguh suatu ironi karena pada saat yang sama pendidikan formal modern ternyata seakan telah gagal mendidik manusia untuk menjadi manusia yang sesungguhnya.

\section{Ke Arah Pendidikan Yang Humanistik}

Tujuan pembangunan secara makro adalah terbentuknya manusia seutuhnya. Arah tujuan pembangunan ini pada hakekatnya mengembalikan manusia pada kodratnya. Pendidikan, sebagaimana terurai dalam prolog artikel ini merupakan salah satu subsistem dari pembangunan, dianggap paling korelat untuk mewujudkan citacita di atas.

Jika pendidikan diharapkan dapat mewujudkan konsep pembentukan manusia seutuhnya, maka jawaban yang dianggap relevan adalah penyelenggaraan pendidikan yang menggunakan landasan "pendekatan humanistik". Pendidikan yang berlandaskan konsep humanistik pada hakekatnya bertujuan untuk menciptakan kondisi belajar mengajar yang memberikan peluang bagi anak didik untuk mengaktualisasikan kemampuan yang ada pada dirinya. Dengan pendekatan humanistik orang tidak perlu kawatir bahwa anak didik hanya menjadi orang-orang alim tapi 
bodoh. Tujuan dari pendidikan yang memakai pendekatan humanistik adalah justru untuk menopang tujuan institusional bagi tercapainya tujuan-tujuan kurikuler sampai dengan tujuan instruksional yang digariskan oleh kurikulum sekolah. Tujuan pokok dari pendidikan yang humanistik adalah agar anak didik mendapatkan perlakuan yang manusiawi dengan meng-hargai martabatnya sebagai pribadi-pribadi yang memiliki potensi untuk tumbuh dan berkembang. Dengan demikian, tugas para pendidik adalah agar dapat menciptakan kondisi belajar mengajar sedemikian rupa sehingga anak didik memperoleh peluang untuk mengaktualisasikan dirinya sesuai dengan bakat dan kemampuan masing-masing.

Selanjutnya, beliau mensinyalir hasil studi Simon dan Kirchenbaun, bahwa apabila anak didik dilibatkan ke dalam proses belajar mengajar dimana kepada mereka diberi peluang untuk menentukan nilai-nilai mereka sendiri dalam usahanya menuju "self actualization", maka sikap apatis, ulah menolak dan bertingkah akan menjadi sangat berkurang, sehingga akan menimbulkan gairah untuk belajar, bersikap toleran, dan berpikir secara lebih kritis. Hal ini sebenarnya tidak lain adalah karena mereka merasa dihargai (dimanu-siakan), dipercaya dan diberi kesempatan untuk menunjukkan kemampuan yang memiliki nilai tersendiri bagi mereka. Pe-nerimaan dan pengakuan dari pihak guru, bahwa pada dasarnya anak didik adalah individuindividu yang multi talented, pa-da gilirannya menuntut sikap dan ke-sadaran para guru, supaya di dalam menjalankan tugasnya tidak cenderung untuk semata-mata mengacu kepada pengembangan domain kognitif dengan mengabaikan perkembangan domain afektif dan psikomotorik.

Untuk mewujudkan paradigma humanis dalam proses pendidikan sebagaimana yang dimaksud diperlukan juga adanya penciptaan kondisi tertentu yang pada gilirannya akan dapat men-dukung tercap telah menawarkan ada tujuh kondisi yang diperlukan agar tercapainya pendidikan yang humanis. Yaitu

1) kondisi untuk mewujudkan pengem-bangan dan jati diri,

2) kondisi untuk kesempatan membangun budaya dan individu belajar,

3) kondisi agar anak mampu menentukan dirinya sendiri,

4) kondisi pembelajaran oleh guru, 
5) kondisi untuk mengembangkan belajar dengan discoveri dan inquiri,

6) kondisi sekolah dan masyarakat

7) kondisi managerial pendidikan dan penyelenggaraan pendidikan.

\section{DAFTAR PUSTAKA}

Damanhuri, Didin S. dan Aruf Satria. 1997. Pendidikan Nasional dan Rekonstruksi Peradaban Abad 21.

Djohar, MS. Dr. Prof. Pembangunan Pendidikan Berwawasan Kema-nusiaan. 1998.

Rahardjo, Mudjia. Dr. Prof. M. Si., Quo Vadis Pendidikan Islam, UIN Malang, 2006

Setjoatmodjo, Pranyoto. 1993. Pembaharuan Konsep Kemanusiaan dalam Pendidikan.

Sudarwan,. 2008. Kriteria Budaya Pendidikan Keberbakatan.

Pasiak, Taufik. Revolusi IQ/EQ/SQ, : Antara Neurosains dan Alqur'an, Mizan, 2002. 